\begin{tabular}{|c|l|}
\hline Title & Developmental Stages and Germ Cell Lineage of the Loach (Misgurnus anguillicaudatus) \\
\hline Author(s) & Fujimoto, Takafumi; Kataoka, Takashi; Sakao, Suzu; Saito, Taiju; Y amaha, Etsuro; A rai, Katsutoshi \\
\hline Citation & $\begin{array}{l}\text { Zoological Science, 23(11), 977-989 } \\
\text { https:/doi.org/10.2108/2sj.23.977 }\end{array}$ \\
\hline Issue Date & 2006-11 \\
\hline Doc URL & http://hdl.handle.net/2115/32972 \\
\hline Rights & (c) 日本動物学会/本文献の公開は著者の意思に基づくものである \\
\hline Type & article \\
\hline File Information & i0289-0003 23-11-977.pdf \\
\hline
\end{tabular}

Instructions for use 


\title{
Developmental Stages and Germ Cell Lineage of the Loach (Misgurnus anguillicaudatus)
}

\author{
Takafumi Fujimoto $^{1 *}$, Takashi Kataoka1, Suzu Sakao', Taiju Saito², \\ Etsuro Yamaha ${ }^{2}$ and Katsutoshi Arai ${ }^{1}$ \\ ${ }^{1}$ Laboratory of Aquaculture Genetics and Genomics, Division of Marine Life Science, \\ Graduate School of Fisheries Sciences, Hokkaido University, 3-1-1 Minato-cho, \\ Hakodate, Hokkaido 041-8611, Japan \\ ${ }^{2}$ Nanae Fresh Water Laboratory, Field Science Center for Northern Biosphere, \\ Hokkaido University, Nanae, Kameda 041-1105, Japan
}

\begin{abstract}
The staging of embryonic and larval development, and the germ cell lineage of the loach, Misgurnus anguillicaudatus, are described. Fertilized eggs were obtained by artificial insemination. For the convenience of detailed observation and photography of the external appearance, we use dechorionated embryos. Through a series of operations, these embryos were cultured at $20^{\circ} \mathrm{C}$ in an incubator. Embryonic and larval development of the loach was divided into five periods: cleavage, blastula, gastrula, segmentation, and hatching. Stages were assigned within each of these periods. Developmental stages were determined and named by morphological features and somite number. The staging series were photographed and tabulated. The germ cell lineage was then elucidated by whole mount in situ hybridization of mRNA expression of the germ-cell-specific marker vasa and histological analysis. Primordial germ cells (PGCs) of the loach derived from the cleavage furrows of 8-cell stage embryos began proliferation in the late blastula period and migrated to the gonadal anlagen through a migration pathway similar to that of the zebrafish. However, it is characteristic of the loach that PGCs migrate a long distance and stay in the posterior part of the yolk-extension region.
\end{abstract}

Key words: loach, Misgurnus anguillicaudatus, developmental stage, germ cell lineage, PGCs

\section{INTRODUCTION}

The staging of embryonic and larval development of target species is indispensable to studies of developmental mechanisms in these species. Developmental stages have been determined for a number of teleost fish species. The most basic form of developmental staging has been based on the description of landmark morphological features rather than on the elapsed time after fertilization or embryonic body length. Small laboratory fishes such as the medaka and the zebrafish are frequently used as model animals in developmental biology. The developmental stages in these species have been described in great detail (Iwamatsu, 1994, 2004; Kimmel et al., 1995). However, the developmental stages in other fish species need detailed description to facilitate the manipulation of embryos and research on embryonic development.

Primordial germ cells (PGCs) are the founding cells in the germ-line lineage. PGCs arise as a small population of cells and segregate from the somatic-cell lineage early in embryogenesis (reviewed by Wylie, 1999; Raz, 2002).

\footnotetext{
* Corresponding author. Phone: +81-138-40-8887; Fax : +81-138-40-5537; E-mail: motchan@ fish.hokudai.ac.jp
}

doi:10.2108/zsj.23.977
PGCs migrate to the gonadal anlagen during embryonic and larval development, and then differentiate into gametes in the gonads. In many animal species, only cells containing a particular type of cytoplasm (polar plasm in Drosophila, germ plasm in anurans) develop into PGCs (reviewed by Ikenishi, 1998). Recently, genes that are specifically expressed in this cytoplasm and in PGCs were identified (reviewed by Wylie, 1999). For example, vasa-related genes, which can be employed as marker genes of germline cells, were isolated in several species.

In teleosts, the origin of germ-line cells has been studied in several species. Histologically, the origin of PGCs can be traced back to the early somite stage (goldfish, KazamaWakabayashi et al., 1999), the gastrula stage (medaka, Gamo, 1961; Barbas conchonius, Timmermans and Taverne, 1989), or the late blastula stage (zebrafish, Nagai et al., 2001) on the basis of morphological criteria, such as a roundish shape, relatively large size, large nucleus, and clear nuclear membrane. Cytochemically, the germ cell lineage has also been revealed by detection of vasa mRNA expression by means of whole mount in situ hybridization (WM-ISH) (zebrafish, Yoon et al., 1997; medaka, Shinomiya et al., 2000 ; rainbow trout, Yoshizaki et al., 2000 ; goldfish, Otani et al., 2002 ; ukigori, Saito et al., 2004). These studies demonstrated species-specific differences in the origin and the migration route of PGCs. Therefore, descriptions of the 
germ cell lineage in more fish species are needed to elucidate the general principles of how they originate and migrate.

The developmental stages of the loach, Misgurnus anguillicaudatus (family Cobitidae, order Cypriniformes) have been reported in the past (Watanabe et al., 1948), and our previous study described in detail the developmental process from cleavage to the gastrula stage (Fujimoto et al., 2004). In $M$. fossilis, a species closely related to $M$. anguillicaudatus and widely used in Russia for in studies of developmental biology (Kostomarova, 1991), developmental stages have also been defined in detail. As experimental animals, Misgurnus spp. are very interesting from the point of view of chromosome manipulation to induce gynogenesis, androgenesis, and various polyploidies (reviewed by Arai, 2001), advanced biotechnologies to produce chimeric fish (Nakagawa and Ueno, 2003), nuclear transplantation (Gasaryan et al., 1979), and transgenics (Nam et al., 2001). Moreover, clonal lines that produce unreduced gametes have been discovered in a natural population (Morishima et al., 2002). In short, loaches are ideal for certain types of experimental studies.

In recent years, PGCs have become a useful tool in teleost biotechnology, including genetic modification, cryopreservation, and surrogate propagation (reviewed by Saito and Yamaha, 2004). Natural polyploidy and clonal reproduction in the loach are suitable for experiments using PGCs. However, there is no information on the germ cell lineage in the loach. In this study, we have described, on the basis of morphological features, the developmental stages of the loach from cleavage to the hatching of the larva. We also determined the germ cell lineage from cleavage to the hatching of the larva, in order to facilitate use of the loach for developmental engineering by means of PGCs.

\section{MATERIALS AND METHODS}

\section{Eggs and sperm}

To obtain eggs and sperm, mature loaches (Misgurnus anguillicaudatus) were caught during the spawning season from June to July in paddy fields and waterways in Kitamura, Sorachi County, Hokkaido, Japan. The collection of gametes and fertilization of eggs was performed as previously described (Fujimoto et al., 2004). About $150-350$ embryos per dish were cultured at $20^{\circ} \mathrm{C}$ in plastic petri dishes (diameter $85 \mathrm{~mm}$ ) filled with about $50 \mathrm{ml}$ tap water.

\section{Stage definitions}

For convenience in the observation and photography of the external appearance, embryos were dechorionated with Ringer's solution $(7.5 \mathrm{~g} / \mathrm{L} \mathrm{NaCl}, 0.2 \mathrm{~g} / \mathrm{L} \mathrm{KCl}$, and $0.2 \mathrm{~g} / \mathrm{L} \mathrm{CaCl}$ ) containing $0.1 \%$ trypsin and $0.4 \%$ urea. Dechorionated embryos before the completion of epiboly were transferred to Ringer's solution containing $1.6 \%$ albumen; embryos after the completion of epiboly were transferred to a culture solution containing $1.8 \mathrm{mM} \mathrm{MgCl}_{2}$ and 1.8 $\mathrm{mM} \mathrm{CaCl}$. Through a series of operations, embryos were cultured at $20^{\circ} \mathrm{C}$ in an incubator. Developmental stages were defined by morphological characteristics. For more detailed information on developmental stages after the onset of somitogenesis, the number of somites of embryos fixed in $10 \%$ formaldehyde was counted every hour from 16 to 48 hours post-fertilization (hpf). Somite numbers are expressed herein as a minimum value, maximum value, average, and standard deviation, using more than 22 embryos per count.

Hatching time was calculated from the number of hatching lar- vae, produced by three females, counted every hour after $41 \mathrm{hpf}$ Three batches of fertilized eggs derived from a single female were prepared and the progeny were cultured without dechorionation. The hatching rate during each hour was calculated by the cumulative number of hatched larvae per total number in each dish. The average of the cumulative hatching rate in the group was calculated using the hatching rate of the three batches. In addition, the average of the cumulative hatching rates in all batches derived from the three females was calculated every hour.

\section{Determination of primordial germ cells}

The origin and the migration of PGCs during embryogenesis were examined by detection of vasa mRNA using whole mount in situ hybridization (WM-ISH). WM-ISH was performed by staining with a single color and with two colors, as previously described (Jowett and Lettice, 1994), with modifications. Expression of vasa was detected with an antisense digoxigenin-labeled vasa RNA probe transcribed from an approximately $0.56 \mathrm{~Kb}$ fragment of the 3'UTR region of zebrafish vasa cDNA (Yoon et al., 1997). Fluorescein-labeled probes from zebrafish no tail (Schulte-Merker et al., 1994) and goldfish MyoD (Otani et al., 2002) were used as markers to clarify the spatial location of PGCs in embryos during the gastrula and segmentation periods, respectively.

Antisense RNA probes were generated from plasmids as follows: vasa plasmid was cut with $\mathrm{Bam} \mathrm{HI}$ and transcribed with $\mathrm{T7}$ polymerase; no tail plasmid was cut with Eco RI and transcribed with T3 polymerase; and MyoD plasmid was cut with Hin dIII and transcribed with T3 polymerase. For WM-ISH, dechorionated embryos at every stage were fixed in $4 \%$ paraformaldehyde in phosphate buffered saline (PBS) for 20 to $30 \mathrm{~h}$ at $4^{\circ} \mathrm{C}$. Fixed embryos were stored in $100 \%$ methanol at $-20^{\circ} \mathrm{C}$ until use. The embryos were rehydrated and washed three times with PBS containing $0.1 \%$ Tween 20 (PBT) for $5 \mathrm{~min}$ each. The embryos were then treated with Proteinase $\mathrm{K}\left(10 \mu \mathrm{g} / \mathrm{mL}\right.$ in PBS) at $37^{\circ} \mathrm{C}$ for $5 \mathrm{~min}$ for the blastula to gastrula period, for $15 \mathrm{~min}$ for 1 -somite to 20 -somite stage embryos, and for $30 \mathrm{~min}$ for embryos older than the 20-somite stage to the hatching stage. Embryos were postfixed in $4 \%$ paraformaldehyde in PBS for 20 min and then washed three times with PBT for $5 \mathrm{~min}$ each. The embryos were prehybridized for 3 hour at $62^{\circ} \mathrm{C}$ in hybridization buffer $(50 \%$ formamide, $5 \times$ standard sodium citrate (SSC), $50 \mu \mathrm{g} / \mathrm{mL}$ heparin, $500 \mu \mathrm{g} / \mathrm{mL}$ Torula Yeast RNA, $0.1 \%$ Tween 20 ) and hybridized in the same buffer containing RNA probes (approximately $0.1 \mu \mathrm{g} / \mathrm{mL}$ ) overnight at $62^{\circ} \mathrm{C}$. The embryos were washed at $62^{\circ} \mathrm{C}$ for 10 min with $50 \%$ formamide in $2 \times$ SSC, $0.1 \%$ Tween 20 ; for 10 min with $25 \%$ formamide in $2 \times$ SSC, $0.1 \%$ Tween 20 ; for 10 min with $2 \times$ SSC, $0.1 \%$ Tween 20 ; and four times for $15 \mathrm{~min}$ with $0.2 \times \mathrm{SSC}, 0.1 \%$ Tween 20 . Following washes were performed at room temperature (RT) in PBT twice for $5 \mathrm{~min}$ and then in blocking solution (PBT with 10\% blocking reagent (Roche)) for 1 hour. The embryos were then incubated overnight at $4^{\circ} \mathrm{C}$ with 1/250-diluted anti-fluorescein-POD, Fab fragments (Roche) in blocking solution and washed 8 times for $15 \mathrm{~min}$ with PBT. The embryos were then incubated with DAB substrate in peroxide buffer (Roche). When the color had developed to the desired extent, they were washed 4 times for $5 \mathrm{~min}$ with PBT. They were then incubated overnight at $4^{\circ} \mathrm{C}$ with $1 / 8000$-diluted anti-digoxigenin-AP, Fab fragments (Roche) in blocking solution, washed 3 times for 30 min with blocking solution at RT, and washed 3 times for $5 \mathrm{~min}$ in staining buffer (100 mM Tris $\mathrm{HCl} \mathrm{pH} \mathrm{9.5,} 50 \mathrm{mM} \mathrm{MgCl}, 100 \mathrm{mM} \mathrm{NaCl}, 0.1 \%$ Tween 20). The embryos then were incubated with staining solution (3.375 mg/mL NBT and $1.75 \mathrm{mg} / \mathrm{mL} \mathrm{BCIP}$ in staining buffer) in the dark at $4^{\circ} \mathrm{C}$. When the color had developed to the desired extent, the embryos were washed 4 times for 5 min with PBT and then refixed with $4 \%$ paraformaldehyde in PBS overnight at $4^{\circ} \mathrm{C}$. The refixed embryos were stored at $4^{\circ} \mathrm{C}$ in PBS and observed with a SZX 12 stereomicroscope (Olympus). For the identification of cells stained with vasa probes, WM-ISH samples at the hatching stage 
were dehydrated with a graded butyl-alcohol series and embedded in paraffin. Serial sections were cut at $12-\mu \mathrm{m}$ thickness and slightly stained with eosin. The location of vasa-positive cells was compared with hematoxylin-eosin stained PGCs.

In hatching larvae, the position of the PGCs was detected by histological analysis. Larvae were fixed every 24 hours after the hatching stage at $48 \mathrm{hpf}$ in Bouin's fixative for $3 \mathrm{~h}$. Fixed larvae were stored in $80 \%$ ethanol, then dehydrated with a graded butylalcohol series and embedded in paraffin. Serial sections were cut at 8- $\mu \mathrm{m}$ thickness and stained with hematoxylin-eosin according to the standard procedure. PGCs were confirmed on the basis of their histological characteristics, such as a roundish shape, relatively large size, large nucleus and clear nuclear membrane.

\section{RESULTS}

\section{Embryonic development in the loach}

Embryonic development of the loach was divided into the cleavage, blastula, gastrula, segmentation, and hatching periods. Each period was subdivided into several stages. The staging of development from the cleavage period to the gastrula period was performed according to a previous work by Fujimoto et al. (2004). Developmental stages were named on the basis of morphological features, according to the developmental stages of zebrafish (Kimmel et al., 1995).

The stages of the cleavage period were modified. The length of the cleavage period had been defined previously as the term corresponding to the stages from 2- to $1 \mathrm{k}$-cells. In this paper, the cleavage period was defined as the term from the 2- to 64-cell stage in order to correspond to the developmental stages of other fish species, such as the zebrafish (Kimmel et al., 1995) and ice goby (Arakawa et al., 1999).

\section{Cleavage period}

Loach eggs were activated on contact with water without any participation of sperm, and the chorion began to swell to form a perivitelline space. The cytoplasm started to move toward the animal pole, and subsequently the blastodisc was formed at 30 minutes post-fertilization (mpf) (Fig. 1A). No lipid globules were observed in the yolk, and yolk granules were present in the cytoplasm of the blastoderm. The cleavage pattern in the loach, as in other teleosts, is typical meroblastic cleavage. Cell divisions of the initial ten cleavage cycles are synchronous, and each cleavage occurs about every 27 min on average (Fujimoto et al., 2004). Early cleavage was especially highly synchronous among the blastomeres of a single blastoderm.

2-cell stage (1 h $10 \mathrm{~min}$ ) (Fig. 1B)

The $1^{\text {st }}$ cleavage furrow began to form at about $60 \mathrm{mpf}$. Two-cell embryos that had formed a clear cleavage furrow were observed at $70 \mathrm{~min}$.

4-cell stage (1 h $30 \mathrm{~min}$ ) (Fig. 1C)

The $2^{\text {nd }}$ cleavage furrow formed transversely to the first in the two blastomeres. The blastodisc at this stage consisted of four blastomeres allocated in a $2 \times 2$ array on the yolk.

8-cell stage (2 h) (Fig. 1D)

The $3^{\text {rd }}$ cleavage furrows formed vertically to the second cleavage furrow in the four blastomeres. The blastodisc at this stage consisted of eight blastomeres allocated in a $2 \times 4$ array on the yolk.

16-cell stage (2 h 30 min (Fig. 1E))

The $4^{\text {th }}$ cleavage furrows were formed parallel to either side of the $2^{\text {nd }}$ cleavage furrow. The 16 blastomeres in the blastodisc were arranged in a $4 \times 4$ array.

32-cell stage (2 h 50 min) (Fig. 1F)

The $5^{\text {th }}$ cleavage produced 32 blastomeres in the blastodisc. An irregular tier of blastomeres formed in the central part of the blastodisc by oblique cell division. However, the blastomeres in the marginal part of the blastodisc were in a single layer. The blastodisc sometimes consisted of 32 blastomeres in a single layer, such as in a $4 \times 8$ array.

64-cell stage (3 h 20 min) (Fig. 1G)

The blastodisc became a bi-layer of cells as the $6^{\text {th }}$ cleavage furrows formed latitudinally in each blastomere.

\section{Blastula period}

The blastula period was divided into early and late terms by the mid-blastula transition. The early term comprised the 128-, 256-, 512- and 1k-cell stages and approximately corresponded to the morula stage. The mid-blastula transition was determined by the transition from synchronous cleavage to asynchronous cleavage at $5 \mathrm{~h} 20 \mathrm{~min}$ after fertilization (Fujimoto et al., 2004). In the early term of the blastula period, the number of blastomeres of the blastoderm increased by synchronous cleavage. In the late term, each developmental stage was determined by the morphological characteristics described below.

128-cell stage (3 h $50 \mathrm{~min}$ ) (Fig. 1H)

The blastodisc assumed a high-mound shape as multiple cell layers formed. The surface of the blastodisc became smoother than the blastodisc of the cleavage period.

256-cell stage (4 h $10 \mathrm{~min}$ ) and 512-cell stage (4 h $40 \mathrm{~min}$ ) (Fig. 11,J)

These stages were a part of the synchronous-cleavage stage. Although the synchronization of cell division showed slight time lags between the marginal region and animalpole region of the blastodisc, cell cycles in neighboring cells were almost synchronous (Fujimoto et al., 2004).

1-k cell stage (5 h $10 \mathrm{~min}$ ) (Fig. 1K)

The $10^{\text {th }}$ cleavage produced about 1,000 blastomeres in the blastodisc. This stage was the transition between synchronous and asynchronous cleavage. Around this stage, the external yolk syncytial layer formed in the marginal part of the blastodisc by cell proliferation without cytoplasmic division.

Oblong stage (6 h) (Fig. 1L)

The shape of the embryo was ellipsoidal. The internal yolk syncytial layer formed in the central part of the bottom of the blastoderm.

Sphere stage (7 h) (Fig. 1M)

The boundary bump between the enveloping layer located at the blastoderm surface and the yolk cell surface became flat. Both the major and minor axis were approximately equal in size, and the embryos were spherical in shape.

Dome stage and $30 \%$ epiboly stage (8 h) (Fig. 1N, O)

At $8 \mathrm{hpf}$, the embryos began epiboly. The blastoderm formed a dome-like shape due to the bulging of the internal yolk syncytial layer toward the animal pole in the center of the bottom of the blastoderm. Embryos developed to $30 \%$ of the epiboly stage, meaning that the blastoderm covered about $30 \%$ of the yolk cell by epiboly. 

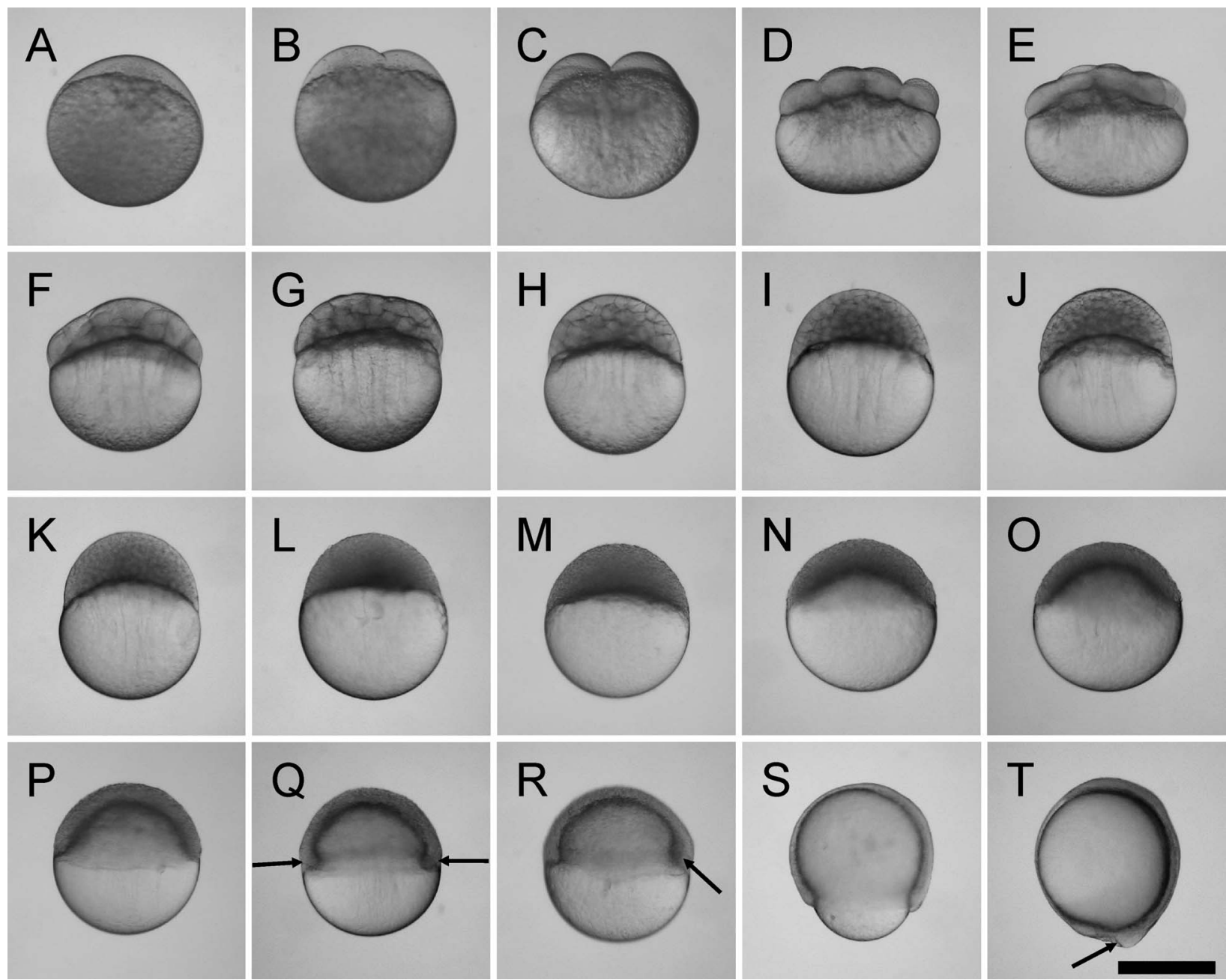

Fig. 1. Embryonic development during the cleavage, blastula and gastrula periods in the loach. A, blastodisc formation (30 min); $\mathbf{B}, 2$-cell

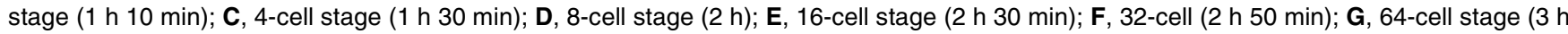
20 min); H, 128-cell stage (3 h 50 min); I, 256-cell stage (4 h 10 min); J, 512-cell stage ( 4 h 40 min); K, 1 k-cell stage (5 h 10 min); L, oblong stage (6 h); $\mathbf{M}$, sphere stage $(7 \mathrm{~h}) ; \mathbf{N}$, dome stage $(8 \mathrm{~h}) ; \mathbf{O}, 30 \%$ epiboly stage $(8 \mathrm{~h}) ; \mathbf{P}, 50 \%$ epiboly stage $(9 \mathrm{~h}) ; \mathbf{Q}$, germ ring stage (10 h); arrows indicate the germ ring; R, embryonic shield stage (10 h); arrow indicates the embryonic shield; $\mathbf{S}, 70 \%$ epiboly stage (12 h); $\mathbf{T}, 100 \%$ epiboly stage (15 h); arrow shows the tail bud. Scale bar indicates $500 \mu \mathrm{m}$.

\section{Gastrula period}

In the gastrula period, involution, convergence, and extension movements were observed, forming the germ ring and the embryonic shield, and consequently establishing the hypoblast and epiblast lineages of the embryo. The beginning of the gastrula period was recognized as germ ring formation after the $50 \%$ epiboly stage at $9 \mathrm{hpf}$. After formation of the embryonic shield, epiboly progressed at $10 \%$ per hour.

\section{$50 \%$ epiboly (9 h) (Fig. 1P)}

Half of the yolk cell was covered with the blastoderm progressing by epiboly.

Germ ring stage and embryonic shield stage (10 h) (Fig. $1 \mathrm{Q}, \mathrm{R})$

Movement by epiboly stopped at the equator of the yolk sphere at this stage. The germ layers (hypoblast and epiblast) formed at the leading edge of the epiboly. On the dorsal side, the embryonic shield formed in part of the germ ring, after which epiboly restarted toward the vegetal pole.

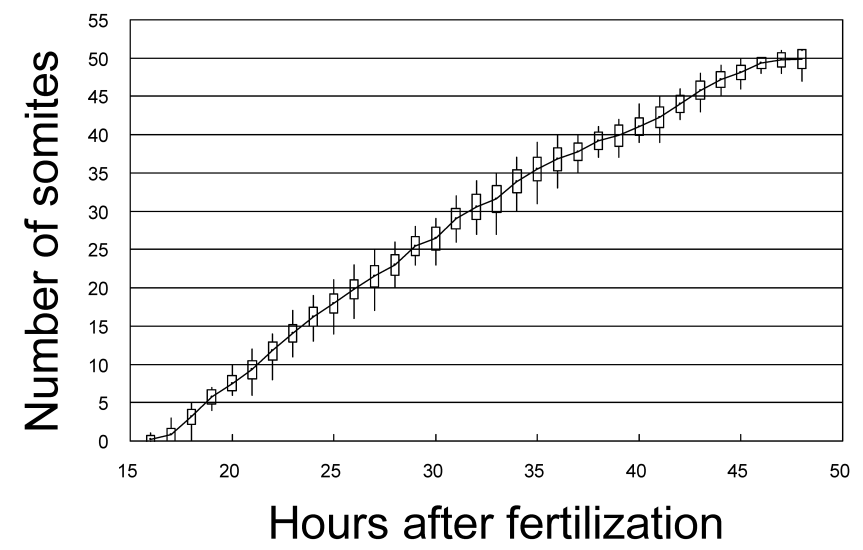

Fig. 2. The number of somites during the segmentation period at $20^{\circ} \mathrm{C}$ in the loach. The box height indicates the SD for each development time. Bars indicate the ranges of the maximum and the minimum number of somites for each development time. 
$70 \%$ epiboly stage (12 h) (Fig. 1S)

The blastoderm covered about $70 \%$ of the yolk cell. The embryonic shield elongated toward the animal pole. $100 \%$ epiboly stage (15 h) (Fig. 1T)

The blastoderm completely covered the yolk cell, reaching the $100 \%$ epiboly. The tail bud was evident as a swelling at the posterior region of the embryonic body near the site of yolk-plug closure.

\section{Segmentation period}

Somitogenesis in this period extended from the end of epiboly to just prior to hatching. During this period, tissues and organs differentiated from germ layers by cellular interactions. In particular, the visual and auditory organs at the anterior end of the embryo became useful morphological characteristics by which to identify developmental stages. The somites consisting of blocks of mesodermal cells on both sides of the neural tube also showed distinct morphological features. Somitogenesis proceeded sequentially and with periodicity from the trunk to the tail, and the number of somites present each hour was a suitable index of developmental stage. Therefore, we defined developmental stages on the basis of both the abovementioned morphological features and the number of somites.

Somite formation began at $16 \mathrm{hpf}$ in the central part of the embryonic body. Somite number increased on average by five pairs every three hours, with the total number of somites reaching approximately 50 pairs at 48 hpf (Fig. 2). Although the average somite number every hour was used as a developmental index, variation of up to eight somites was observed among embryos in the hourly counts.

2-somite stage (17 h) (Fig. 3A)

The first somite was observed at $16 \mathrm{hpf}$ in a few embryos, and many embryos showed from one to three
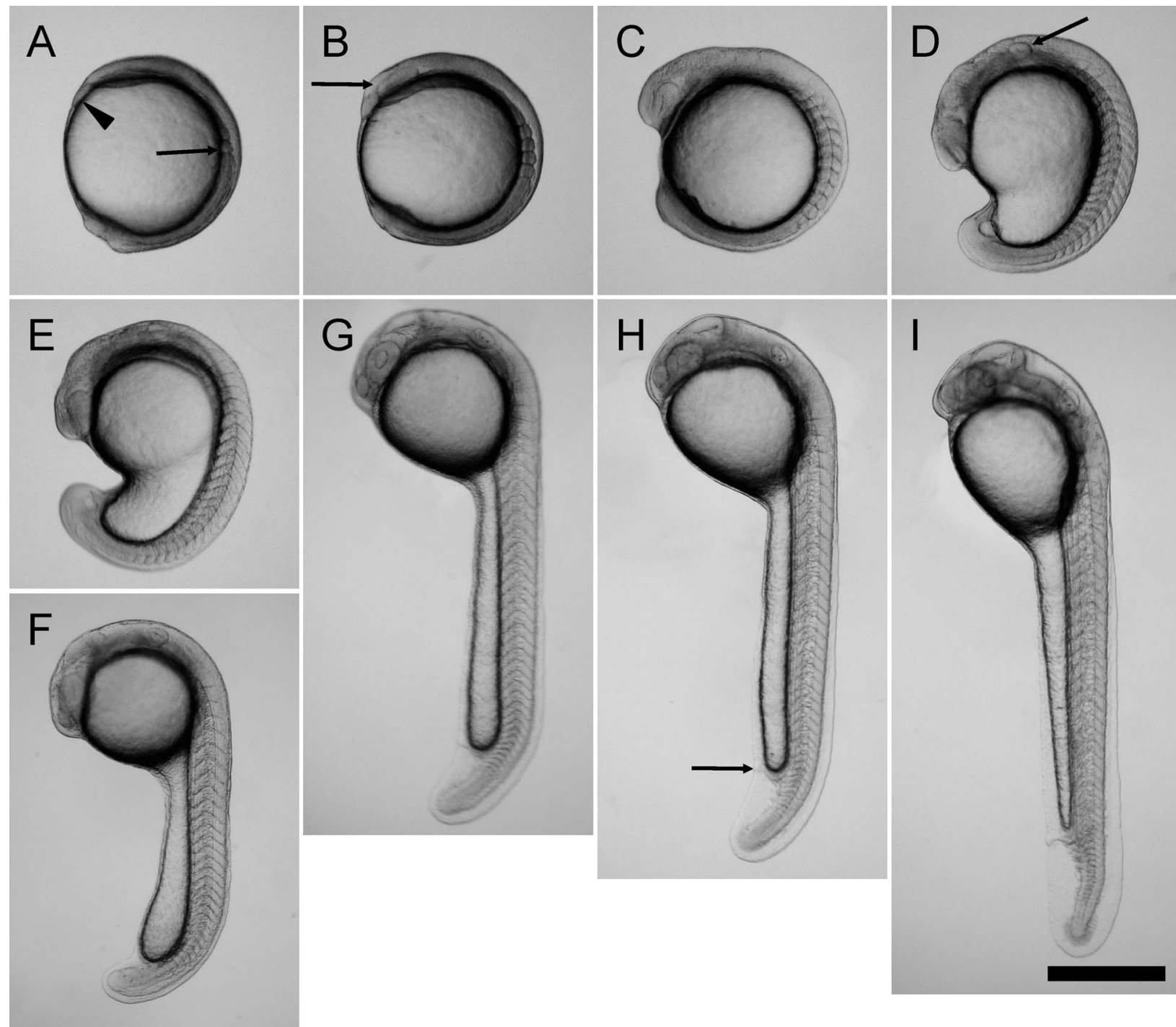

\section{$\mathrm{H}$}
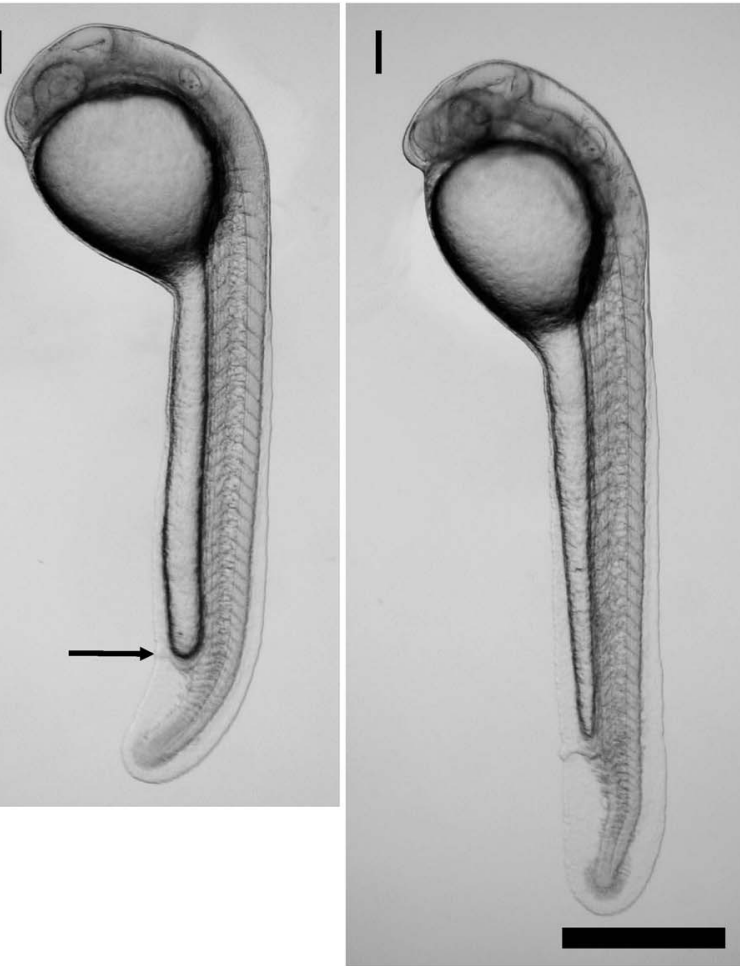

Fig. 3. Embryonic development during the segmentation period in the loach. A, 2-somite stage (17 $\mathrm{h}$ ); arrow indicates the posterior boundary of somite 2; arrowhead indicates the polster; B, 4-somite stage (18 h); arrow indicates the optic primordium; C, 12-somite stage (22 h); D, 20somite stage (26 h); arrow indicates the otic vesicle; E, 22-somite stage (27 h); F, 30-somite stage (32 h); G, 34-somite stage (34 h); H, 38 somite stage $(37 \mathrm{~h})$; arrow indicates the anus; I, 44-somite stage (42 h). Scale bar indicates $500 \mu \mathrm{m}$. 
pairs of somites at $17 \mathrm{hpf}$.

4-somite stage (18 h) (Fig. 3B)

A pair of rudimentary optic vesicles appeared in the cephalic region (Fig. 4A, B) and Kupffer's vesicle arose in the tail bud region. The optic primordium and Kupffer's vesicle enlarged from the 6-somite to the 10-somite stage, and a horizontal crease formed in the optic primordium (Fig. 4C, D).

\section{2-somite stage (22 h) (Fig. 3C)}

The shape of somites in the anterior region changed from elliptical to chevron-shaped.

20-somite stage (26 h) (Fig. 3D)

A pair of otic placodes was distinguishable from the surrounding region at $25 \mathrm{~h}$ (18-somite stage) (Fig. 5A, B), formed by thickening. As in the following stages, the otic vesicles were clearly distinguishable at the 20-somite stage due to hollowing of the otic placodes (Fig. 5C). Around the same time, a constriction formed in the posterior region of the yolk cell. The cavities of the otic vesicles subsequently expanded with the progression of development (Fig. 5D).
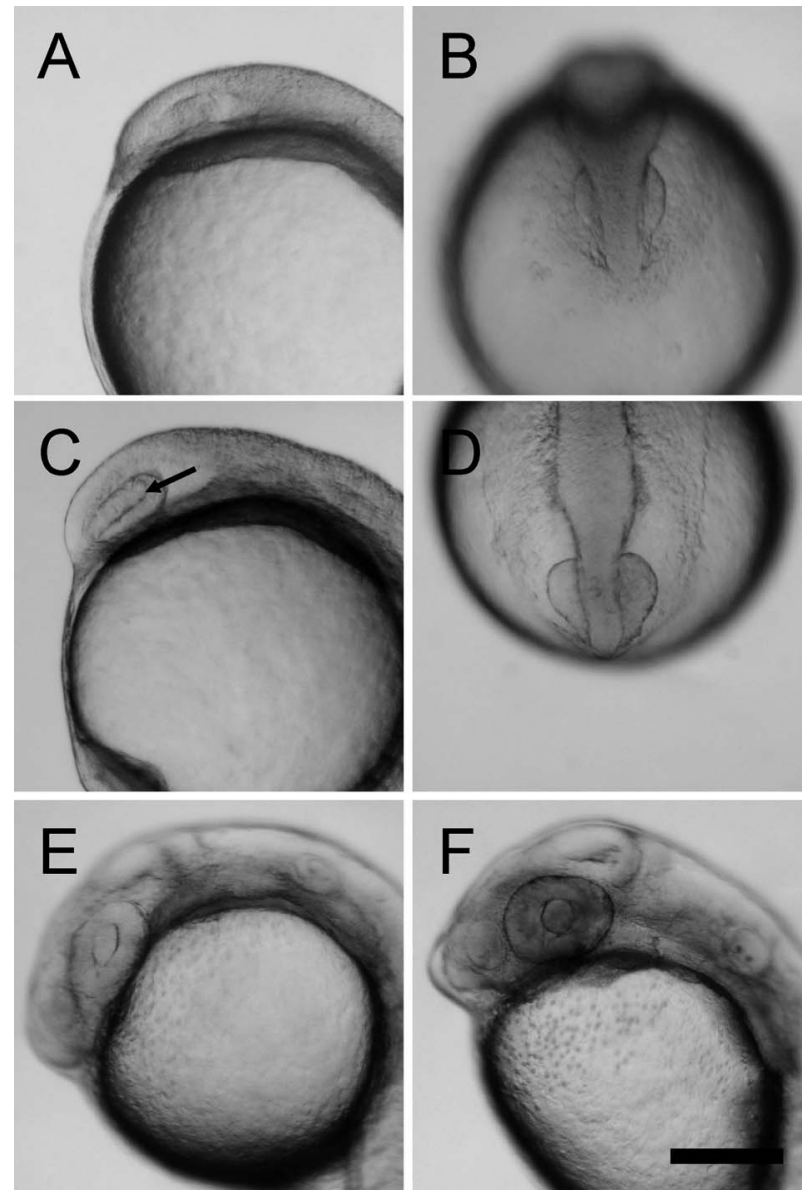

Fig. 4. Development of optical organs during the segmentation period in the loach. A, B, formation of the optic primordium at 4somite stage; lateral (A) and animal pole (B) views; C, D, formation of a horizontal crease (arrow) in an optic primordium, that is, optic vesicle formation at the 10-somite stage; lateral (C) and animal pole (D) views; $\mathbf{E}$, formation of the optic cup and lens placode at the 30somite stage; $\mathbf{F}$, pigmentation in the retina at the 44-somite stage. Scale bar indicates $200 \mu \mathrm{m}$.
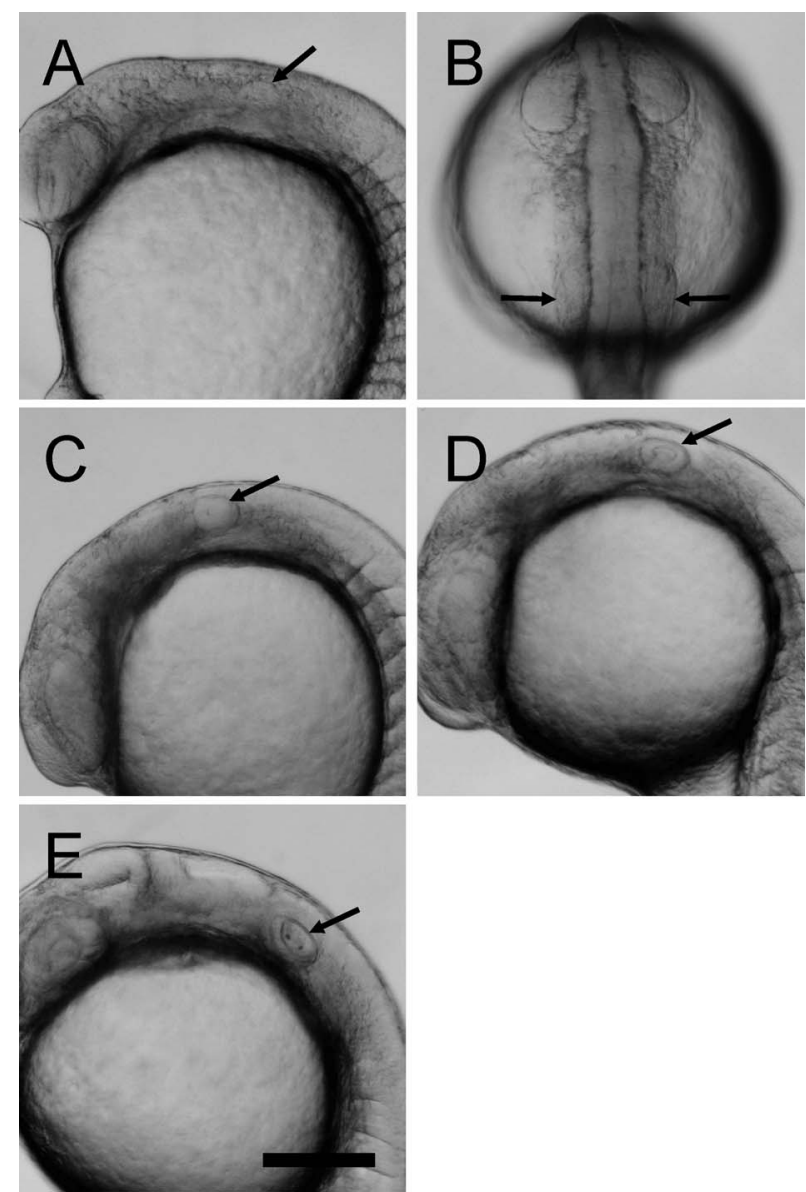

Fig. 5. Development of the auditory organ in the loach. A, B, Otic placode (arrows) at 18-somite stage; lateral view (A) and dorsal view (B); C, otic vesicle (arrow) at the 20-somite stage; D, otic vesicle (arrow) at the 25-somite stage; the cavity becomes larger; $\mathbf{E}$, otolith formation in the otic vesicle (arrow) at the 34-somite stage. Scale bar indicates $200 \mu \mathrm{m}$.

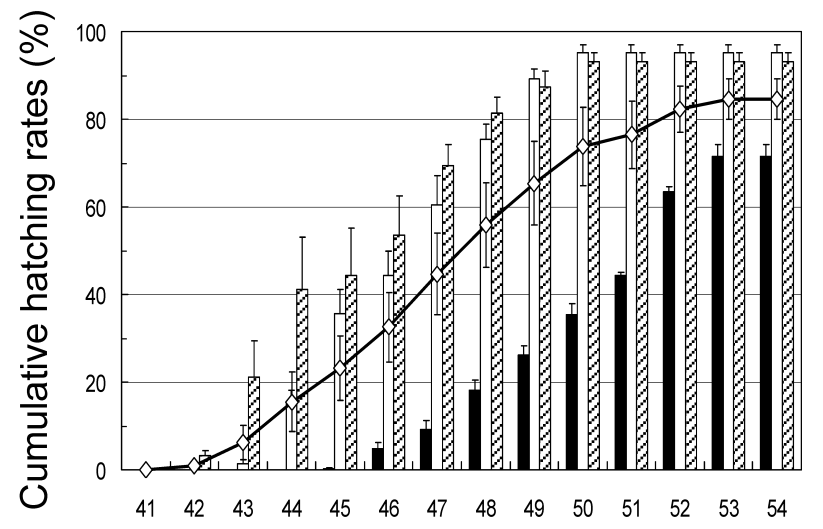

\section{Hours after fertilization}

Fig. 6. Hatching rates after $41 \mathrm{~h}$ post-fertilization in the loach. Columns indicate the means of cumulative hatching rates in each batch. The line indicates the average value of the hatching rates from three batches for each developmental time. Bars indicate SE. 

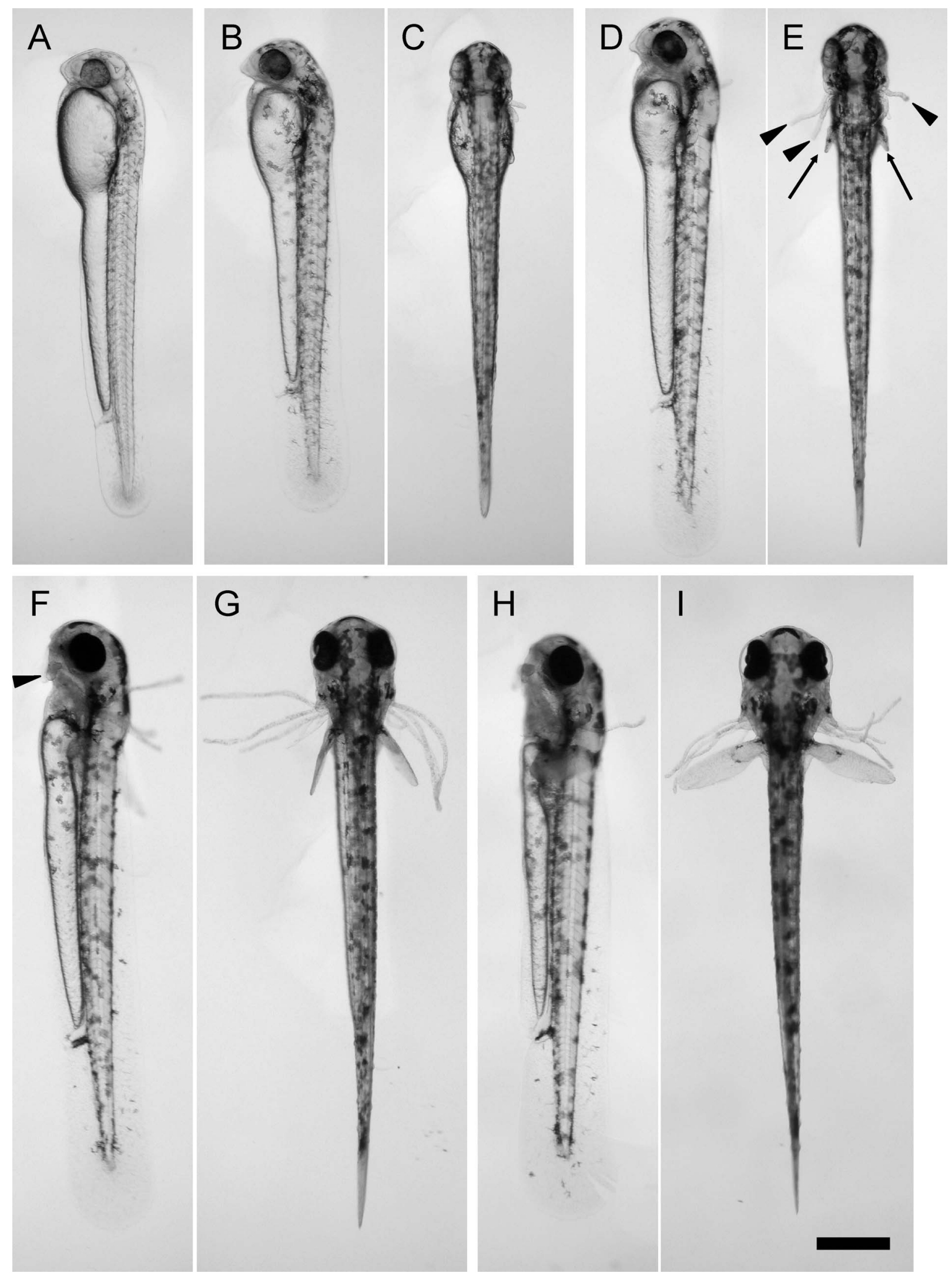

Fig. 7. Development in the loach after hatching. A, 50-somite stage (48 h), hatching; B, C, lateral (B) and dorsal (C) views of the 1 st fry stage $(60 \mathrm{~h})$; melanophores appear in the entire body; D, E, lateral (D) and dorsal (E) views of the 2nd fry stage (72 h); arrows indicate the pectoral fins; arrowheads indicate short external gills; F, G, lateral $(F)$ and dorsal $(G)$ views of the 3rd fry stage ( 96 h); arrowhead indicates the barbel; $\mathbf{H}, \mathbf{I}$, Lateral $(\mathrm{H})$ and dorsal $(\mathrm{I})$ views of the 4 th fry stage $(120 \mathrm{~h})$. Scale bar indicates $500 \mu \mathrm{m}$. 
The yolk extension became clearly delimited from the yolk ball and elongated posteriorly with the extension of the trunk region at the 22-somite stage (Fig. 3E).

30-somite stage (32 h) (Fig. 3F)

The optic vesicles developed into optic cups. Each lens placode was distinguishable in the hollow in the central part of the optic vesicle (Fig. 4E). Kupffer's vesicle almost disappeared.

\section{4-somtie stage (34 h) (Fig. 3G)}

Two obvious otoliths appeared in each otic vesicle (Fig. $5 E)$. The yolk-extension region stopped elongating. The tail region became separated from the yolk and then elongated toward the posterior. The tail mesoderm became segmented into 4 or 5 somites. The median fin fold formed. 38-somite stage (37 h) (Fig. 3H)

The anus became evident at the end of the yolk-extension region. A weak heartbeat appeared in the cavity between the region in front of the eye and the yolk ball. 44-somite stage (42 h) (Fig. 3l)

The retinae became slightly pigmented (Fig. 4F). Melanophores also appeared in several parts of the body. The yolk extension shrank toward the anus.

\section{Hatching period}

Embryos began to hatch nearly simultaneously in each batch derived from a single female parent fish, but at different times between experimental batches derived from different females (Fig. 6). In the earliest batch, hatching started at $42 \mathrm{hpf}$ and approximately half of the embryos had hatched by $46 \mathrm{hpf}$, while in the latest batch, they were at 45 hpf and $52 \mathrm{hpf}$, respectively. The average hatching time was at $48 \mathrm{hpf}$ across the three groups.

50-somite stage (48 h) (Fig. 7A)

Just after hatching, larvae settled at the bottom of the dish and rarely swam, although they showed motility in response to artificial stimulation. Somite formation was com-
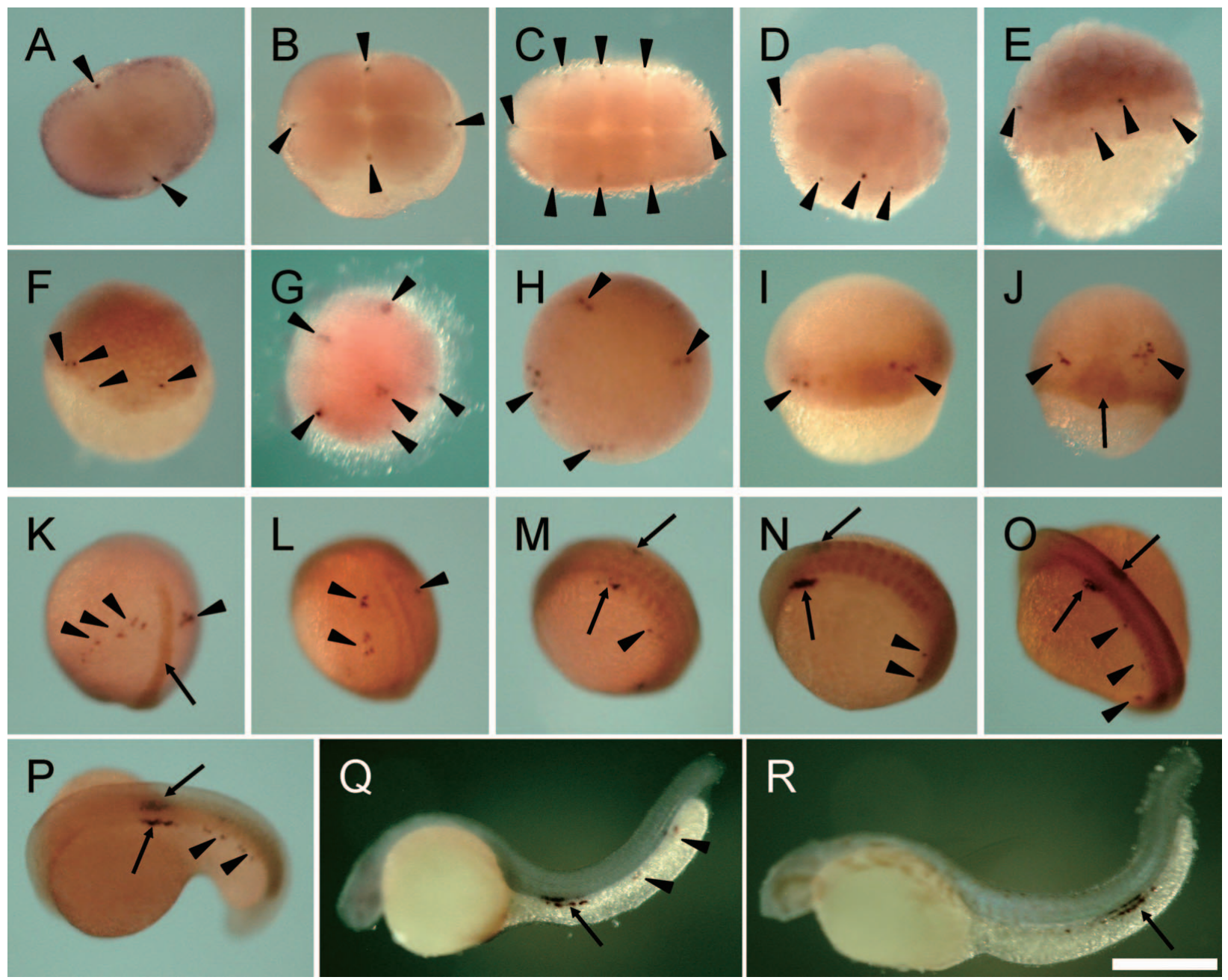

Fig. 8. Expression of vasa during embryonic stages of the loach. Embryos were hybridized with a zebrafish vasa antisense probe. A, 2-cell stage; B, 4-cell stage; C, 8-cell stage; D, 32-cell stage; E, 64-cell stage; F, 1k-cell stage; G, sphere stage; $\mathbf{H}$, dome 30\% epiboly stage; I, embryonic shield stage; J, 70\% epiboly stage; K, 100\% epiboly stage; L, 1-somite stage; $\mathbf{M}, 6$-somite stage; $\mathbf{N}$, 10-somite stage; $\mathbf{O}$, 20-somite stage; P, 22-somite stage; $\mathbf{Q}$, 38-somite stage; R, hatching stage. Arrows indicate the embryonic shield in (J-K) and cluster of vasa-positive cells in (M-R). Arrowheads indicate vasa signals. (J-K), Region expressing no tail was stained light brown; (L-P), region expressing $M y o D$ was stained light brown. Scale bar indicates $500 \mu \mathrm{m}$. 
plete at about fifty somites.

$1^{\text {st }}$ fry stage $(60 \mathrm{~h})$ (Fig. 7B, C)

The onset of formation of the pectoral fins and external gills was observed on both sides of the larval body. The retinae were clearly pigmented, and numerous melanophores appeared over the entire body.

$2^{\text {nd }}$ fry stage $(72$ h) (Fig. 7D, E)

Small pectoral fins and short external gills were observed in the process of formation. The yolk ball became markedly smaller, disappearing behind the body in the dorsal view.

$3^{\text {rd }}$ fry stage (96 h) (Fig. 7F, G)

The external gills grew to their maximal length. The barbels appeared around the rostral region.

$4^{\text {th }}$ fry stage $(120 \mathrm{~h})$ (Fig. $\left.7 \mathrm{H}, \mathrm{I}\right)$

The size of pectoral fins increased more laterally than in the previous stage. Yolk size was clearly reduced. Larvae were able to swim, and about 12 to $24 \mathrm{~h}$ later began to feed actively.

\section{Germ cell lineage in the loach \\ PGC migration during embryogenesis}

To clarify the origin and migration route of the PGCs, the localization of vasa mRNA during embryogenesis was analyzed by WM-ISH using zebrafish antisense vasa RNA probes. The expressionx of no tail and MyoD served as markers for the notochord and germ ring in the gastrula period, and for the paraxial mesoderm and somites in the segmentation period, respectively. Localization of vasa transcripts was not observed at the 1-cell stage before the first cleavage. At the 2-cell and 4-cell stages, vasa mRNA strongly aggregated at both ends of the first and the second cleavage furrows (Fig. 8A, B). Signals of vasa localization were also observed at one or both ends of the third cleavage furrows at the 8-cell stage, though more weakly compared with those in the earlier cleavage furrows (Fig. $8 \mathrm{C}$ ). About four to eight vasa signals were observed in the subsequent synchronous-cleavage stages (Fig. 9). Aggregates of vasa were located on cell boundaries until the 32-cell stage (Fig.

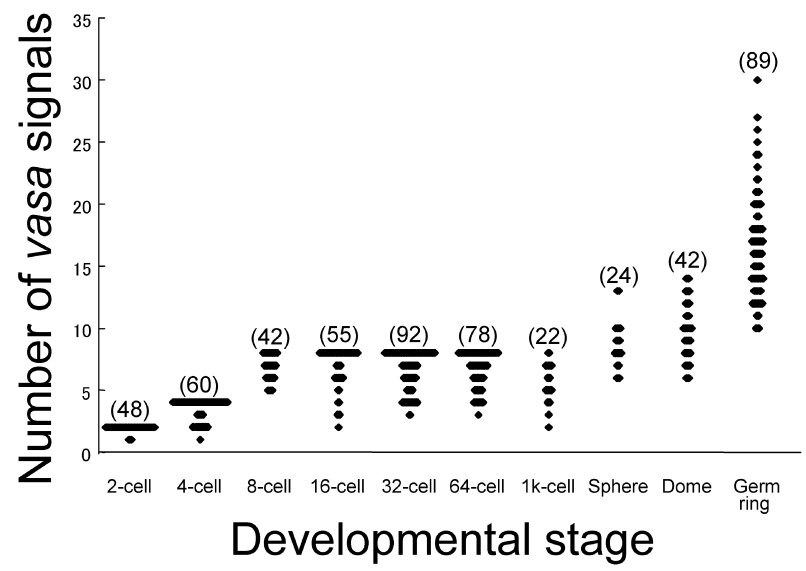

Fig. 9. Number of vasa signals or vasa-positive cells in loach embryos from the cleavage to gastrula stages. Dots indicate the total number of vasa signals or vasa-positive cells per embryo in each stage. Numbers in parenthesis indicate the number of specimens used for WM-ISH in each stage.
8D); after the 64-cell stage, each aggregate was observed in a single blastomere (Fig. 8E). An increase in vasa-positive cells was not observed until the $1 \mathrm{k}$-cell stage. After the late blastula period, vasa-positive cells increased in number (Fig. 9). In these stages, vasa signals changed in form to expression throughout cells, as opposed to the small spots seen in former stages (Fig. 8F, G).

Some clusters of proliferated vasa-positive cells were present in the marginal part of the blastoderm (Fig. 8G). The number of clusters differed among embryos, due to differences in the number of vasa signals at the 16-cell stage. From the dome to the $30 \%$ epiboly stages, vasa-positive cells generating each cluster were slightly scattered, and their number increased (Fig. 8H, 9). At the embryonic shield stage, vasa-positive cells were frequently located in the marginal part of the blastoderm, the same region expressing no tail (Fig. 8I). However, some clusters of vasa-positive cells were located around the animal region more than in the marginal region in some embryos. At the $70 \%$ epiboly stage, vasa-positive cells near the embryonic shield moved to a more anterior region lateral to the shield, while others remained at the leading edge of epiboly (Fig. 8J). At the $100 \%$ epiboly stage, vasa-positive cells were located in rows between the dorsal equatorial region and the ventral posterior region (Fig. 8k). At the 1-somite stage early in somitogenesis, vasa-positive cells were aligned along both sides of the embryonic body (Fig. 8L). As somitogenesis progressed, vasa-positive cells formed clusters in the near-anterior somites (Fig. $8 \mathrm{M}$ ). At the 10 - to 15 -somite stage, many vasa-positive cells were clustered on both sides of the midline in the first to fifth somites (Fig. $8 \mathrm{~N}$ ). However, a small number of vasa-positive cells were isolated in the posterior region of the clusters (Fig. $8 \mathrm{~N}$ ). At the 20 -somite stage, after constriction of the yolk and the onset of yolk extension, the clusters began to migrate to the posterior (Fig. 8O), and at the 22-somite stage were located at the base of the yolkextension region (Fig. 8P). However, the posterior isolated vasa-positive cells did not change position. As development progressed, the clusters moved to the posterior end of the yolk extension (Fig. 8Q), finally reaching the posterior region of the yolk extension in the newly hatched larva (Fig. 8R).

\section{PGCs migration after hatching}

The position of PGCs from days 2 to 7 post-fertilization (dpf) was identified by histological observation. In paraffin sections stained with hematoxylin-eosin, PGCs were confirmed by their morphology, as mentioned in the preceding section. In 48-hpf larvae at hatching, PGCs were located around the extra-embryonic coelom connecting to the yolk syncytial layer (Fig. 10A, B). In transverse sections from post-WM-ISH samples of hatching larvae, vasa-positive cells were observed in the same position as the PGCs recognized in H-E stained histological sections (Fig. 10C, D). The position of PGCs in 3-dpf embryos was lateral to the gut and ventral to the trunk muscles and the pronephric ducts (Fig. 10E, F). PGCs migrated on the dorsal side of the gut in 4-dpf embryos (Fig. 10G, H) and were located dorsal to the gut in 5-dpf embryos (Fig. 10l, J). In 7-dpf embryos, PGCs reached the gonadal anlagen separated from the dorsal mesentery in the upper part of the body cavity (Fig. 10K, L). 

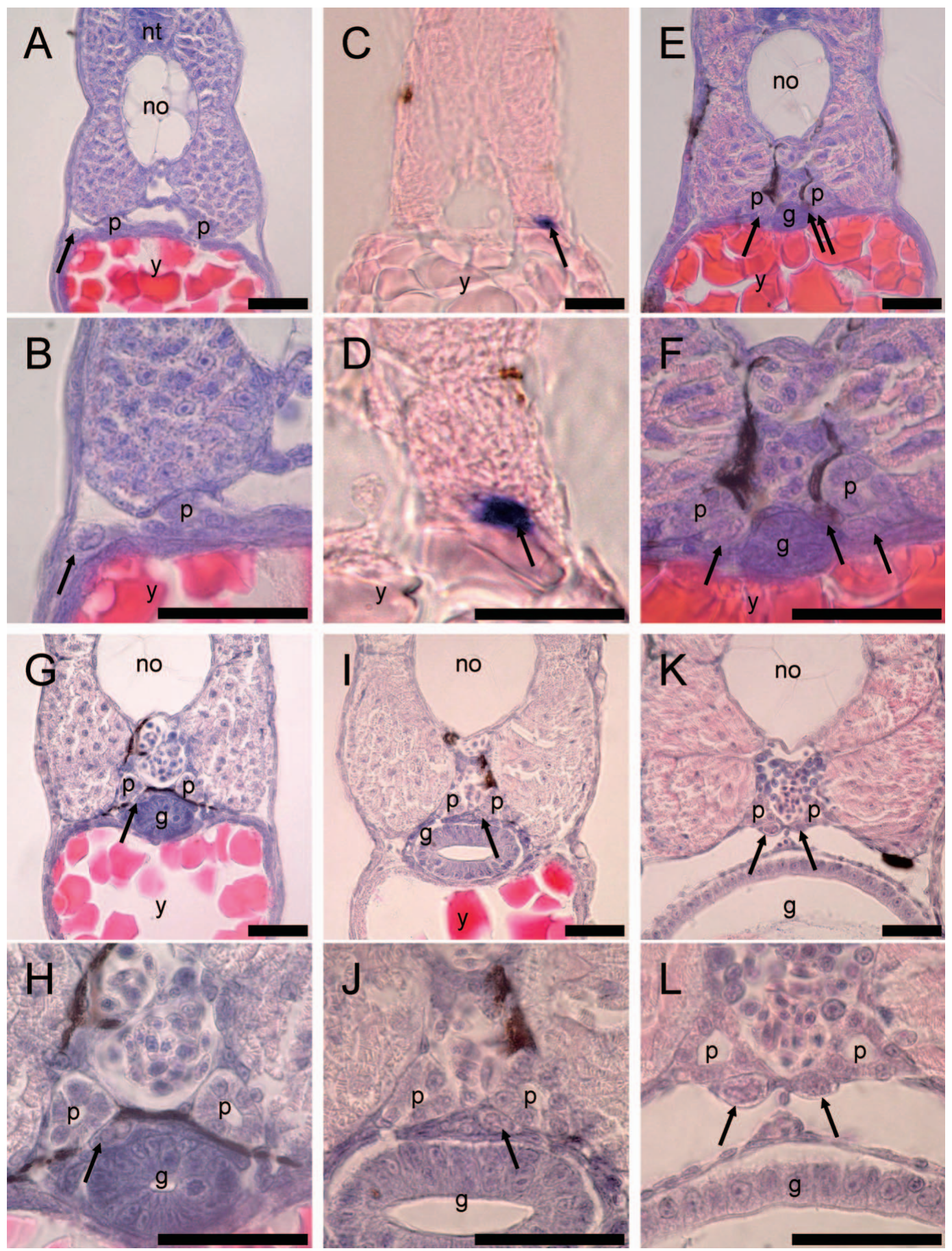

Fig. 10. Distribution of PGCs in transverse sections of loach larvae after hatching. A-D, 2 day post-fertilization (dpf); E, F, 3 dpf; G, H, 4 dpf; I, J, 5 dpf; K, L, 7 dpf. B, D, F, H, J and L are higher magnifications of A, C, E, G, I and K, respectively. (A, B, E-L) are 8- $\mu$ m, HE-stained transverse sections. $(C, D)$ are 12- $\mu \mathrm{m}$ transverse sections following WM-ISH with vasa probes. Arrows indicate PGCs. g, gut; no, notochord; nt, neural tube; $p$, pronephric duct; $y$, yolk. Scale bars indicate $50 \mu \mathrm{m}$.

\section{DISCUSSION}

\section{Development of the loach}

In the present study, the developmental process of the loach was staged from embryogenesis through the hatching of the larva. Table 1 summarizes the developmental stages of the loach. Our previous study reported similarity between development in the loach from cleavage to the gastrula stage and that in some other fishes (Fujimoto et al., 2004). The present study allows the developmental stages during the segmentation and hatching periods of the loach to be compared with those of other fish species, such as medaka (Iwamatsu, 1994, 2004), zebrafish (Kimmel et al., 1995), ice goby (Arakawa et al., 1999), and M. fossilis (Kostomarova, 1992).

The number of somites is usually used to define devel- 
Table 1. Developmental stages of loach embryos at $20^{\circ} \mathrm{C}$.

\begin{tabular}{|c|c|c|c|}
\hline Stage name & Time & Characteristics & Fig. No. \\
\hline \multicolumn{4}{|l|}{ Cleavage period } \\
\hline 2-cell & $1 \mathrm{~h} 10 \mathrm{~min}$ & & $1 \mathrm{~B}$ \\
\hline 4-cell & $1 \mathrm{~h} 30 \mathrm{~min}$ & & $1 \mathrm{C}$ \\
\hline 8-cell & $2 \mathrm{~h}$ & & $1 \mathrm{D}$ \\
\hline 16-cell & $2 \mathrm{~h} 30 \mathrm{~min}$ & & $1 \mathrm{E}$ \\
\hline 32-cell & $2 \mathrm{~h} 50 \mathrm{~min}$ & Tier formation in a central part of blastomeres & $1 \mathrm{~F}$ \\
\hline 64-cell & $3 \mathrm{~h} 20 \mathrm{~min}$ & & $1 \mathrm{G}$ \\
\hline \multicolumn{4}{|l|}{ Blastula period } \\
\hline 128-cell & $3 \mathrm{~h} 50 \mathrm{~min}$ & & $1 \mathrm{H}$ \\
\hline 256-cell & $4 \mathrm{~h} 10 \mathrm{~min}$ & & 11 \\
\hline 512-cell & $4 \mathrm{~h} 40 \mathrm{~min}$ & & $1 \mathrm{~J}$ \\
\hline $1 \mathrm{k}-$ cell & $5 \mathrm{~h} 10 \mathrm{~min}$ & E-YSL ${ }^{1)}$ formation, mid-blastula transition occurs after this stage & $1 \mathrm{~K}$ \\
\hline Oblong & $6 \mathrm{~h}$ & I-YSL ${ }^{2)}$ formation, ellipsoidal shape & $1 \mathrm{~L}$ \\
\hline Sphere & $7 \mathrm{~h}$ & Spherical shape & $1 \mathrm{M}$ \\
\hline Dome $~ 30 \%$ epiboly & $8 \mathrm{~h}$ & Beginning of epiboly & $1 \mathrm{~N}, \mathrm{O}$ \\
\hline \multicolumn{4}{|l|}{ Gastrula period } \\
\hline $50 \%$ epiboly & $9 \mathrm{~h}$ & Half coverage of a yolk cell by the blastoderm & $1 \mathrm{P}$ \\
\hline Germ ring embryonic shield & $10 \mathrm{~h}$ & Arrest of the epiboly, germ ring and embryonic shield formation & $1 Q, R$ \\
\hline $70 \%$ epiboly & $12 \mathrm{~h}$ & & 1S \\
\hline $100 \%$ epiboly & $15 \mathrm{~h}$ & Complete coverage of the yolk cell by the blastoderm, tail bud & $1 \mathrm{~T}$ \\
\hline \multicolumn{4}{|l|}{ Segmentation period } \\
\hline 2-somite & $17 \mathrm{~h}$ & First somatic furrow & $3 \mathrm{~A}$ \\
\hline 4-somite & $18 \mathrm{~h}$ & Optic primordium, Kupffer's vesicle & $3 B, 4 A^{*}, B^{\star}$ \\
\hline 12-somite & $22 \mathrm{~h}$ & Somites transformation into a chevron shape & $3 C$ \\
\hline 20-somite & $26 \mathrm{~h}$ & Otic vesicle, constriction of the yolk cell & $3 \mathrm{D}, 5 \mathrm{C}$ \\
\hline 30-somite & $32 \mathrm{~h}$ & Optic cup and lens placode & $3 F, 4 E$ \\
\hline 34-somite & $34 \mathrm{~h}$ & Median fin fold, tail extension, otolith & $3 G, 5 E$ \\
\hline 38-somite & $37 \mathrm{~h}$ & Anus formation, weak heartbeat & $3 \mathrm{H}$ \\
\hline 44-somite & $42 \mathrm{~h}$ & Early pigmentation in retina and skin & $3 \mathrm{I}, 4 \mathrm{~F}$ \\
\hline \multicolumn{4}{|l|}{ Hatching period } \\
\hline 50-somite & $48 \mathrm{~h}$ & Hatch & $7 \mathrm{~A}$ \\
\hline 1st fry & $60 \mathrm{~h}$ & $\begin{array}{l}\text { Beginning of formation of pectoral fins and external gills, appearance } \\
\text { of pigments in whole boly }\end{array}$ & 7B, C \\
\hline 2nd fry & $72 \mathrm{~h}$ & Small pectral fins and short external gills & 7D, E \\
\hline 3rd fry & $96 \mathrm{~h}$ & Maximal length of external gills, clear reduction in yolk size & $7 F, G$ \\
\hline 4th fry & $120 \mathrm{~h}$ & Swimming & $7 \mathrm{H}, \mathrm{I}$ \\
\hline
\end{tabular}

1) external yolk syncytial layer. ${ }^{2)}$ internal yolk syncytial layer. ${ }^{*}$ Figures show embryo of 10-somite stage.

opmental stages, because of the periodic increase during embryogenesis (Gorodilov, 2004). However, the final number of somites is usually species specific. The total of 50 or so final somites in the loach is approximately equivalent to the number in M. fossilis (55 somites; Kostomarova, 1991), but is greater than the total in medaka (35 somites; Iwamatsu, 1994, 2004), zebrafish (30-34 somites; Kimmel et al., 1995) and ice goby (36 somites; Arakawa et al., 1999). Various organs such as optic vesicles, lens placodes, and otic vesicles, which comprise typical milestones in developmental staging, differentiate at different somite numbers in different fish species. The optic vesicles appear with almost the same timing (in the early, 3- to 6-somite stage) in the loach, zebrafish, ice goby, and $M$. fossilis, but in medaka form before somitogenesis. Otic vesicles and lens placodes in the loach form at the 20- and 30-somite stages, respectively, but at the 10- and 20-25-somite stages, respectively, in zebrafish, ice goby, and $M$. fossilis. Generally, in developmental staging based on somite number, organs in the loach appear to differentiate at later stages than those in fish species with fewer somites.

The loach seems to hatch at a somewhat earlier stage than some other fishes. Somite formation continues until just after hatching. The loach larvae then remain at the bottom of the culture dish and require an additional three days before they swim actively. In medaka, zebrafish, and goldfish, somitogenesis finishes shortly before hatching, and the larvae begin to swim actively soon after hatching. Loach embryos incubated at $28-30^{\circ} \mathrm{C}$ hatch at $30 \mathrm{hpf}$, whereas zebrafish incubated at approximately the same temperature hatch at $48 \mathrm{hpf}$ (Watanabe et al., 1948). Hatching time in the loach is earlier than in zebrafish, while organogenesis is slower, as mentioned above, which suggests that the loach hatches at an earlier stage of development than the zebrafish.

Average hatching time of three different litters of loaches was $48 \mathrm{hpf}$ at $20^{\circ} \mathrm{C}$, which is similar to the hatching times of $52 \mathrm{hpf}$ at $20-21^{\circ} \mathrm{C}$ and $55 \mathrm{hpf}$ at $19-21^{\circ} \mathrm{C}$ reported by Watanabe et al. (1948) and Suzuki (1953), respectively. Our study showed that hatching time in the loach seems to 
depend on the female parent. In rainbow trout, several androgenetic clonal lines also hatched at different physiological times (Robison et al., 1999). Therefore, we think that variation in hatching time in the loach is due mainly to genetic background, though more detailed study will be required to elucidate this relationship.

\section{Dynamics of PGCs in the loach}

In this study, the PGCs of the loach were detected by WM-ISH the zebrafish vasa probe and by histological observation. In goldfish and ukigori, the germ cell lineage was identified by vasa probes from the zebrafish and ice-goby, respectively (Otani et al., 2002; Saito et al., 2004). Zebrafish vasa probes specifically hybridized in a particular region in the loach embryo, with signals observed in the first, second, and third cleavage furrows and thereafter in selected cells. The location of vasa mRNA in the loach indicated an origin and dynamics of PGCs similar to those reported in other cyprinid fishes (zebrafish, Yoon et al., 1997; goldfish, Otani et al., 2002). When post-WM-ISH samples at the 50-somite stage were sectioned and observed, the position of vasaexpressing cells corresponded to that of PGCs at the same stage revealed by histological observation. These results in the loach embryo suggest that the vasa-positive cells correspond to the PGCs.

Several differences in the origin and migration routes of PGCs have been reported by many studies, in a variety of fish species. Two patterns indicative of the origin of PGCs are evident in fishes: the aggregation of vasa mRNA at cleavage furrows, as in zebrafish (Yoon et al., 1997), goldfish (Otani et al., 2002), and ukigori (Saito et al., 2004), and the distribution of vasa mRNA over the whole blastodisc, as in medaka (Shinomiya et al., 2000) and rainbow trout (Yoshizaki et al., 2000). We traced the origin of PGCs in the loach back to the vasa mRNA aggregation at one or both ends of cleavage furrows at the 8-cell stage, as occurs in other several fish species, but the number of vasa signals differs among species. In zebrafish, only four vasa signals at the first and second cleavage furrows contribute to PGC differentiation, and other small signals at later stages are not distributed to PGCs (Yoon et al., 1997). In goldfish, all eight vasa signals at the third cleavage furrows are distributed to the PGCs (Otani et al., 2002). In ukigori, the number of vasa signals at the 16-cell stage ranges from 4 to 8 , and these signals are distributed to PGCs clustered at $40 \%$ epiboly in embryos (Saito et al., 2004). Saito et al. (2004) noted that the number of PGCs in the loach seems to depend on the number of aggregations, as in ukigori. In addition, the number of PGCs might be influenced by the amount of germinal factor in each aggregation. Ukigori embryos and loach parental lines were obtained from the wild, whereas goldfish and zebrafish embryos are typically obtained from cultured parental lines. There might thus be greater variation in the amount of germinal factor present in eggs from natural populations with large genetic diversity.

From the gastrula period to the segmentation period, proliferated PGCs migrated to the prospective genital ridge region, though the migration pathway differs among fish species. In the loach, proliferation of PGCs begins from the late blastula period. Proliferated PGCs align between the dorsal equatorial region and the ventral posterior at $100 \%$ epiboly. They form clusters on each side of somites 1-5 early in the somite stage, although some clusters remain to in the posterior region. This migration pathway in the loach is quite similar to that in zebrafish from epiboly to the early somite stage. After the early somite stage in the loach, the anterior cluster of PGCs moves posteriorly over the base of the yolk extension, and all PGCs remain in the middle part of the yolk-extension region. In goldfish and zebrafish, the PGC clusters move to the base of the yolk extension and remain in the anterior part of the yolk-extension region, adjacent to the yolk ball (Yoon et al., 1997; Braat et al., 1999; Weidinger et al., 1999; Otani et al., 2002). It is characteristic of the loach that PGCs migrate a long distance and remain in the posterior part of the yolk-extension region. This seems to be due to the greater number of somites in the loach.

In this study, we defined in the loach the developmental stages from cleavage to the hatched larva prior to feeding and traced the germ cell lineage from its origin to its appearance in the genital anlagen. Our results provide information useful for future investigation of mechanisms of development and for the application of the loach as an experimental model in developmental engineering.

\section{ACKNOWLEDGMENTS}

We thank Dr. S. Otani (Hokkaido University) for his kind guidance in this study; Mr. Y. Sotozaki and Mr. S. Shoji of the Loach Farming Cooperation in Kitamura, Sorachi County, Hokkaido, for supplying loach samples; Mr. S. Kimura, Mrs. M. Takagi, and the members of the Nanae Fresh Water Laboratory, Field Science Center for Northern Biosphere, Hokkaido University, and the Laboratory of Aquaculture Genetics and Genomics, Graduate School of Fisheries Sciences, Hokkaido University. We are indebted to all of these people for their help. This study was supported in part by a Grantin-Aid to the 21st Century COE program from the Ministry of Education, Culture, Sports, Science, and Technology (MEXT), Japan.

\section{REFERENCES}

Arai K (2001) Genetic improvement of aquaculture finfish species by chromosome manipulation techniques in Japan. Aquaculture 197: 205-228

Arakawa T, Kanno Y, Akiyama N, Kitano T, Nakatsuji N, Nakatsuji T (1999) Stages of embryonic development of the ice goby (shirouo), Leucopsarion petersii. Zool Sci 16: 761-773

Braat AK, Zandbergen T, van de Water S, Goos HJT, Zivkovic D (1999) Characterization of zebrafish primordial germ cells: morphology and early distribution of vasa RNA. Dev Dyn 216: 153167

Fujimoto T, Kataoka T, Otani S, Saito T, Aita T, Yamaha E, Arai K (2004) Embryonic stages from cleavage to gastrula in the loach Misgurnus anguillicaudatus. Zool Sci 21: 747-755

Gamo H (1961) On the origin of germ cells and formation of gonad primordia in the medaka, Oryzias latipes. Jpn J Zool 13: 101115

Gasaryan KG, Hung NM, Neyfakh AA, Ivanenkov VV (1979) Nuclear transplantation in teleost Misgurnus fossilis L. Nature 280: $585-587$

Gorodilov YN (2004) Studies of temporal and spatial peculiarities of somitogenesis in fish embryos. Russ J Dev Biol 35: 92-105

Ikenishi K (1998) Germ plasm in Caenorhabditis elegans, Drosophila and Xenopus. Dev Growth Differ 40: 1-10

Iwamatsu T (1994) Stages of normal development in the medaka Oryzias latipes. Zool Sci 11: 825-839

Iwamatsu T (2004) Stages of normal development in the medaka Oryzias latipes. Mech Dev 121: 605-618 
Jowett T, Lettice L (1994) Whole-mount in situ hybridization on zebrafish embryos using a mixture of digoxigenin- and fluorescein-labelled probes. Trends Genet 10: 73-74

Kazama-Wakabayashi M, Yamaha E, Yamazaki F (1999) The elimination and duplication of lower part of blastoderm effects on the number of primordial germ cells in goldfish. Fish Sci 65: 577582

Kimmel CB, Ballard WW, Kimmel SR, Ullmann B, Schilling TF (1995) Stages of embryonic development of the zebrafish. Dev Dyn 203: 253-310

Kostomarova AA (1991) The loach Misgurnus fossilis. In "Animal species for developmental studies: vertebrates" Ed by TA Dettlaff, SG Vassetzky, Plenum Publishing, New York, pp 125144

Morishima K, Horie S, Yamaha E, Arai K (2002) A cryptic clonal line of the loach Misgurnus anguillicaudatus (Teleostei: Cobitidae) evidenced by induced gynogenesis, interspecific hybridization, microsatellite gynotyping and multilocus DNA fingerprinting. Zool Sci 19: 565-575

Nagai T, Yamaha E, Arai K (2001) Histological differentiation of primordial germ cells in zebrafish. Zool Sci 18: 215-223

Nakagawa M, Ueno K (2003) Production of chimeric loach by cell transplantation from genetically pigmented to orange embryos. Zool Sci 20: 333-338

Nam YK, Noh JK, Cho YS, Cho HJ, Cho K-N, Kim CG, Kim DS (2001) Dramatically accelerated growth and extraordinary gigantism of transgenic mud loach Misgurnus mizolepis. Transgen Res 10: 353-362

Otani S, Maegawa S, Inoue K, Arai K, Yamaha E (2002) The germ cell lineage identified by vasa-mRNA during the embryogenesis in goldfish. Zool Sci 19: 519-526

Raz E (2002) Primordial germ cell development in zebrafish. Semin Cell Dev Biol 13: 489-495

Robison BD, Wheeler PA, Thorgaard GH (1999) Variation in development rate among clonal lines of rainbow trout (Oncorhynchus mykiss). Aquaculture 173: 131-141
Saito T, Yamaha E (2004) Aspects and prospective of surrogate propagation in teleost fish. J Anim Genet 31: 47-55 (in Japanese)

Saito T, Otani S, Fujimoto T, Suzuki T, Nakatsuji T, Arai K, Yamaha E (2004) The germ line lineage in ukigori, Gymnogobius species (Teleostei: Gobiidae) during embryonic development. Int J Dev Biol 48: 1079-1085

Schulte-Merker S, Ho RK, Herrmann BG, Nüsslein-Volhard C (1994) no tail (ntl) is the zebrafish homologue of the mouse $T$ (Brachyury) gene. Development 120: 1009-1015

Shinomiya A, Tanaka M, Kobayashi T, Nagahama Y, Hamaguchi S (2000) The vasa-like gene, olvas, identifies the migration path of primordial germ cells during embryonic body formation stage in the medaka, Oryzias latipes. Dev Growth Differ 42: 317-326

Suzuki R (1953) Studies on the interfamiliar crossing between loach (Misgurnus anguillicaudatus) and goldfish (Carassius auratus). Jpn J Ichthyol 3: 7-14 (in Japanese)

Timmermans LPM, Taverne N (1989) Segregation of primordial germ cells: their numbers and fate during early development of Barbus conchonius (Cyprinidae, Teleostei) as indicated by ${ }^{3} \mathrm{H}-$ thymidine incorporation. J Morphol 202: 225-237

Watanabe M, Kobori N, Matsumoto A (1948) On the development of the Japanese loach. Collect Breed 10: 72-75 (in Japanese)

Weidinger G, Wolke U, Köprunner M, Klinger M, Raz E (1999) Identification of tissues and patterning events required for distinct steps in early migration of zebrafish primordial germ cells. Development 126: 5295-5307

Wylie C (1999) Germ cells. Cell 96: 165-174

Yoon C, Kawakami K, Hopkins N (1997) Zebrafish vasa homologue RNA is localized to the cleavage planes of 2-and 4-cell-stage embryos and is expressed in the primordial germ cells. Development 124: 3157-3166

Yoshizaki G, Sakatani S, Tominaga H, Takeuchi T (2000) Cloning and characterization of a vasa-like gene in rainbow trout and its expression in the germ cell lineage. Mol Reprod Dev 55: 364371

(Received December 5, 2005 / Accepted July 27, 2006) 